\title{
OVERVIEW OF THE IMPACT OF COVID-19 PANDEMIC ON THE NIGERIAN ECONOMY
}

\author{
Nwabueze Prince OKENNA \\ Department of Economic Policy \& Development \\ Gilgal Economic Foundation \& Research Institute, Abuja Nigeria
}

\begin{abstract}
This study took a holistic overview of the economic impact of the Covid-19 pandemic on the economies of developed countries such as the United States of America and developing African countries with Nigeria as the case study.

Nigeria was considered as a choice case study because of her importance, influence, and dominance in the economies of most developing African countries -with Nigeria being referred to as the giant of Africa, her dominance, impact, and economic influence make her the ideal choice. Any impact on her economy will affect the economies of other African nations as she is seen as their big brother.

The study further recommended stringent macroeconomic monetary and fiscal policies that must be implemented to ameliorate the harsh economic effects of the pandemic on both small and largescale businesses including households in the country. In addition, it further shed lights on the current state of the health sector in Nigeria and the need to declare a state of emergency on its current state.
\end{abstract}

Keywords - COVID-19, Developing countries, Africa, Monetary Policy, Fiscal Policy, Exchange Rate, and Nigeria

\section{INTRODUCTION}

According to the Centre for Disease Control (CDC), the COVID-19 is a disease that is caused by a strain of SARSCoV-2 identified and generally referred to as the "coronavirus" or the "novel coronavirus." Not so much information is currently known about the virus. However, it has been acclaimed that it originated from Wuhan China that can affect the human lungs and airways with well-known symptoms such as cough, a high temperature, and shortness of breath.

Currently, there isn't any confirmed treatment for the COVID19 disease as all medical efforts are currently aimed towards relieving the symptoms until the affected patience recovers.

Its means of transmission ranges from spread from person to person through droplets from cough and that is why it has been advised by all health practitioners that social distance should be practiced -at least 2 meters apart in addition to the use of face mask when in a public place, and also, social mass gathering should be avoided.

While our public medical officials are still ascertaining and managing the medical impacts of the virus simultaneously with its known effects, such as the incubation period, signs, and, reaction of the disease, we believe the social and macroeconomic impact will to a large extent depend on how the public respond to it.

The public attitude and response could allow the disease to increase more rapidly based on their conformity with the said guidelines and this could lead to a total shut down of economic activities leading to increased economic cost, a decline in production and economic activities, death of our young and economic viable population, which could ultimately affect economic development especially in developing African countries whose medical care and facilities are in dilapidated conditions and state.

\section{GENERAL OVERVIEW OF THE COVID-19 PANDENMIC}

In 2003, the SARS outbreak that infected approximately 8,000 persons and which killed about 774 people cost the world's economy an estimated amount of 50billion dollars. In 2015, there was a Middle East Respiratory Syndrome (MERS) outbreak in South Korea, and this left about 200 people infected with approximately, 38 deaths with an estimated cost of about 8.5 billion dollars.

It is worth noting that while these other diseases and outbreaks affected some parts of the world, the Coronavirus pandemic affected nearly the whole world -and its devastating effect and untold global unpredicted economic and social hardship cannot be overlooked or ignored.

At the moment, its economic effect is greater and more negative impact than all its predecessors combined -it has made several developed nations handicapped.

According to the Wall Street report, this has led to several global sell-off; the S\&P stock market index of the US companies has fallen by approximately $12 \%$ in the early month of March 2020; making it the worst since the global economic crisis that happened between 2007 - 2008. 


\section{International Journal of Engineering Applied Sciences and Technology, 2020 Vol. 5, Issue 3, ISSN No. 2455-2143, Pages 116-119 \\ Published Online July 2020 in IJEAST (http://www.ijeast.com)}

Also, the world's industrial Chinese market has equally been on lockdown to prevent the spread of the virus in their city and this has significantly impacted the world as over $50 \%$ of the world's manufacturing comes from them (Asian).

According to the World Health Organization (WHO) reports, the Virus was originally declared a global health crisis in January 2020 after it was first diagnosed in Wuhan, China. Following this, it has been seen across 190 countries with developing African countries not exempted.

In the early month of March, it witnessed a huge transmission rate from China to Europe, particularly Italy and Spain. In April 2020, it spread was all over the US that experienced a significant accelerating increase in the number of cases and deaths as well. At the moment, the virus has relapsed more than 9.4 million people across the world with about $1 / 3$ of these cases in the US coupled with over 400 thousand deaths.

Over 80 countries have closed their territorial borders to prevent the spread, businesses, industries, and companies have been ordered to shut down, and the public advised to stay indoor with strict government compliance and stipulated fines and punishments in countries such as Spain, France, India, etc.

The outbreak of this pandemic has impacted the social, political, economic, financial, and religious system's structures of the whole world. The World's leading industrial economies such as the United States, Italy, France, etc are on the verge of exhaustion due to the overwhelming effect and unpredictable impact of the pandemic.

\section{EFFECT ON THE GLOBAL ECONOMY VS DEVELOPING COUNTRIES}

Owing to this pandemic, there is a projection that the world's global economy will shrink piercingly by approximately $3.2 \%$ this year.

The recent World Economic Situation report by the United Nations released in May 2020 indicated that the COVID-19 pandemic has deadened the substantial components of the world's economy, it has also bound and limited economic activities especially that of the manufacturing sector and agriculture as well.

In addition to their report, it has equally unleashed an unpredicted recession since the Great Depression that took place in the 1930s where the world's economy experienced a major slump.

In addition to the $3.2 \%$ contraction that the world economy would experience, it has equally been projected that the global output will decline by approximately 8.5 trillion dollars in the coming 2 years (United Nations World Economic Report, 2020).

Besides this depreciation in the global economy, there is also a projection in the contraction of the world's total trade by $15 \%$ this year (2020) if the estimated world trade is valued at approximately 20trillion US dollars annually as a result of the pandemic.

\section{EFFECTS ON DEVELOPED COUNTRIES SUCH AS THE U.S}

According to a survey report by Bain \& Company conducted in March 2020 at the early stage of the Covid-19 pandemic in the United States, it predicted that about $60 \%$ of their nationals (Americans) have lost their job or been laid off or closed business indefinitely due to the result and outcome of the pandemic in the country.

A report by Karen Harris in March 2020, reveled that the corona virus is negatively affecting livelihood of over $55 \%$ of US workers. According to her reports, about $31 \%$ of the US population have seen their hours or income reduced, $18 \%$ have been laid off either permanently or temporarily, with about $10 \%$ showing businesses have been closed temporarily or permanently.

\section{IMPACTS ON THE ECONOMIES OF DEVELOPING COUNTRIES I.E NIGERIA}

In Nigeria at the moment, as of the 25th of June 2020, the official reports from the NCDC indicated that there are 22614 confirmed cases with 549 deaths.

While the number of cases as compared to other nations are not alarming, her economy could be one of the hardest-hit owing to her decay medical infrastructures, facilities, and her over-dependent on developed European countries both economically and financially in form of aids, grants, and loans from these nations.

The effects of the coronavirus on the Nigerian economy could affect diverse vital sectors such as;

\section{i. Investment and trade opportunities}

It is pertinent to note that Nigeria's trade and investment partners are who are mostly Europe, US and China has shut down their economy and international borders because of the impact of the pandemic to prevent the spread. This will greatly affect Nigeria's national income earnings, reserve, and economy in total.

The retardation of industrial and business activities in these areas rightfully indicates that there will be a global decline in economic activities as well with a higher risk of recession, a hike in the prices of essential services, and much more. In addition to this, companies relying on products imported into the country will be forced to shut down due to a shortage of raw materials needed and increased production cost.

\section{ii. Reduction in the government's financial capacity and earnings with an increased cost to deal with}

According to the Budget office calculation of the Nigerian government, the country could incur an expenditure totaling about 20billion dollars from the crude oil revenue. This 


\section{International Journal of Engineering Applied Sciences and Technology, 2020 Vol. 5, Issue 3, ISSN No. 2455-2143, Pages 116-119 \\ Published Online July 2020 in IJEAST (http://www.ijeast.com)}

amount is approximately 90percent of her total exports. As the world oil price continues to decrease due to shut down of economic activities from the world economies, so is her revenue from the sales of crude oil.

The implication of this is that the government of Nigeria will have little financial backings and earnings to support the economy especially the health sector that is in a dilapidated state and currently, is overstretched. In addition, the various governments (both the federal and states) will all struggle to pay salaries to their worker -contributing to more economic hardship, poverty, and hardship in the society.

\section{iii. Decreased social public expenditure}

Reduction in the public earnings has contributed substantially to the expenses made by the public -this is because this is a 2way process. The public can only spend what they have received or earned. In pure economics at the elementary stage, Savings + Expenditure = Income algebraically represented as $\mathrm{Y}=\mathrm{S}+\mathrm{I}$. It is only what is earned that can be spent. This decline in personal and private earnings has significantly led to a decline in social public expenditure coupled with restrictions in public and social gatherings.

\section{iv. Increased poverty \& economic hardship}

According to the United Nations statistical report, Nigeria currently has the highest amount of extremely poor people in the world today with approximately 95 million people living in abject poverty.

The World Poverty Index of 2020 estimated an average of 4 people falling into the poverty trap in every minute.

The effect of the COVID pandemic will make the situation more severe as the unemployment and poverty rate will certainly be made worsen.

In addition to this, the world economic lockdown will negatively impact Nigeria's earnings from abroad as remittances by her nationals which supports many households and families has significantly declined.

\section{POLICY RECOMMENDATIONS}

This will spell out strategies, policies, and the necessary actions the government must take to ameliorate the economic impact, hardship, and difficulties that the pandemic has caused not just on the government but to the general public and businesses.

At the moment, the priority must be the health sector. A significant amount of the government's allocations and resources during this quarter and period should be channelled to the health sector, and vulnerable in the society.

Based on the above, this research work recommends the following.

1. Declaring a state of emergency on the state of health care system in the country
Prior to the pandemic, the Nigeria's healthcare systems were in deplorable state and the advent of this pandemic has overwhelmed not just these poor facilities and medical personnel, it has also made it difficult for the masses to get the needed medical care.

For the country to have a fighting chance against the Covid pandemic, there must be a general overhauling of the health sector. This includes formulating the right policies, effective allocation and utilization of fund to this sector coupled with ensuring the medical personnel at the fore front of this battle are well taken care of and compensated to encourage and not deter their spirits. Part of what could be done include an effective and prompt payment of hazard allowance, granting these personnel waiver, etc.

The Nigerian government could further lessen the impact of the COVID pandemic on the most exposed, vulnerable, and weak households through tax waivers, incentives, grants, and social loans with a single-digit affordable interest rate. In relation to revamping the economy and boost productivity, this study further recommends the below

\section{Adoption of expansionary Fiscal Policy measure}

Inlay man's term, fiscal policy involves the use of taxes/taxation and government expenditure to control the economy. In this regard, expansionary fiscal monetary policy measures involve the reduction of taxes that are imposed on businesses in the country especially the Small and Medium Scale enterprises -we also advocate for a tax holiday on these businesses especially the ones that are at the brink of folding up.

As regards expenditure, the government should increase her expenditure and finances of projects in the economy -this will create jobs and act as a shock absorber to the economy and to those who lost their jobs owing to this pandemic. At the moment, the social intervention fund been released by the central bank of Nigeria is a welcomed development. Hence, this study further proposes for transparent implementation. These funds should be given to businesses and households who are significantly affected by the pandemic and should not be hijacked or politicized by anyone. Also, there should be a regular and independent audit of these funds for accountability purposes.

\section{Adoption of expansionary monetary and financial policies}

These are policies that would boost the economy and in most cases are done in relation to financial institutions in the country. Here, the authorities will mandate financial institutions to give out loans to certain targeted sectors and businesses in the economy especially to those that are affected greatly by the pandemic.

This policy involves giving loans to the affected sectors, Open market operations (buying of securities and assets by the government to offset businesses and make them more 


\section{International Journal of Engineering Applied Sciences and Technology, 2020 Vol. 5, Issue 3, ISSN No. 2455-2143, Pages 116-119 \\ Published Online July 2020 in IJEAST (http://www.ijeast.com)}

sustainable, etc. In addition, the interest rate for loans should be reduced and made single affordable digit for businesses that are highly impacted by this pandemic.

These actions and policies are all targeted towards reducing inflation, exchange rate, and ultimately to increase the flow and circulation of money in the economy.

This study further recommends the adoption of the expansionary monetary and financial policy by the government of Nigeria and the concerned institutions to ensure the economic effects of the COVID pandemic is lessened.

\section{Adoption of flexible exchange rate}

The exchange rate of the country should be reviewed and made flexible. This is because over 60 percent small and medium scale surviving business in Nigeria imports their raw materials and inputs directly from the international market such as China. A higher interest rate in their transaction and businesses will negatively affect their survival in these trying times. Due to this, this study further recommends the government and policy makers in the country be proactive by implementing flexible business favourable exchange rate in the country.

\section{CONCLUSION}

The overall economic impact of the COVID 19 pandemic cannot be ascertained at the moment because she has not experienced the peak of the crises yet as more cases are still been reported. As at this moment (3rd July 2020), the country's centre for Disease Control (NCDC) put the total confirmed (infected) cases at 24,567.

One thing that has been established is that its impact on unemployment, additional job losses, contribution to poverty, hunger, coupled with a great decline in oil prices cannot be under-estimated. This study, therefore, concludes that drastic economic policies measure must be institutionalized and formulated to aid struggling businesses and SME's in this time of difficulties, palliatives, soft social loans should also be made readily available for households that are the most hit.

Also, this pandemic has revealed the ills and decay in our medical facilities, hospitals, etc. This should be a wakeup call for the government to work on improving the health sector through the provision of adequate funding for its development, training of doctors, medical research, equitable and reasonable wage payment for them (which are not limited to hazard allowance) -this is in an attempt to ensure we provide worldclass medical facilities that will be accessible and affordable not just to the rich in the society, but also to the average Nigerian.

\section{ACKNOWLEDGMENT}

All gratitude and thanks to God for the grace and knowledge He bestowed on me. It is a great privilege to share my thoughts and contributions to existing body of knowledge out there through this medium.

\section{REFERENCES}

[1] Akbulaev, Nurkhodzha \& Mammadov, Ilkin \& Aliyev, Vasif. (2020). ECONOMIC IMPACT OF COVID-19 (Pg. 113-126)

[2] Arora, Snehil. (2020). Sectoral impact of COVID-19.

[3] BBC news 2020. Available here: https://www.bbc.com/news/world-asia-china-51364382

[4] Center for Disease Control (CDC), report 2020. Available here: https://www.cdc.gov/media/releases/2020/s0404covid19-surveillance-report.html

[5] Dutta, Joystu \& Mitra, Ankita \& Mitra, Abhijit. (2020). Impact of COVID lockdown on Employment.

[6] Federal Government of Nigeria (FGN) 2020. Appropriation bill. Available here: https://budgetoffice.gov.ng/index.php/2020appropriation-bill/2020-appropriation-bill/download

[7] IBRD, 2020. The World Bank Poverty Index Report. Available here: https://www.worldbank.org/en/topic/poverty/overview

[8] Karen H, Bain \& Company, 2020. Tracking the Global Impact of the Coronavirus Outbreak.

[9] Michael B. Sauter, Samuel Stebbins, 2020. How the current stock market collapse compares with others in history- Wall Street. Available here: https://eu.usatoday.com/story/money/2020/03/21/stockmarket-collapse-how-does-todays-compareothers/2890885001/

[10] Morsy, Hanan \& Balma, Lacina \& Mukasa, Adamon. (2020). 'Not a Good Time': Economic Impact of COVID19 in Africa.

[11] P.K. Embarek, V. Kerkhove, 2015. Middle East respiratory syndrome coronavirus (MERS-CoV) -current situation 3 years after the virus was first identified. Pg.245-250.

[12] United Nations World Economic Situation and Prospects (WESP) report, 2020. Available here: https://www.un.org/development/desa/dpad/publication/w orld-economic-situation-and-prospects-as-of-mid-2020/

[13] World Health Organization (WHO), coronavirus situation reports 2020. Available here: https://www.who.int/docs/defaultsource/coronaviruse/situation-reports/20200702-covid-19sitrep-164.pdf?sfvrsn=ac074f58 2 